\title{
The Mechanism of Distinguishing Key Factors of Nonpublic Corporation Value Based on Differentiation Methods
}

\author{
Irina Arkadyevna Kaluzhskikh ${ }^{1}$ \\ ${ }^{1}$ Samara State Aerospace University, Samara, the Russian Federation \\ Correspondence: Kaluzhskikh Irina Arkadyevna, Finance and Credit Department, Samara State Aerospace \\ University (SSAU), 34, Moskovskoye shosse, Samara, 443086, the Russian Federation. Tel: 7-917-956-2004.
}

\author{
Received: March 30, 2015 Accepted: April 20, 2015 Online Published: May 14, 2015 \\ doi:10.5539/res.v7n7p262 URL: http://dx.doi.org/10.5539/res.v7n7p262
}

\begin{abstract}
The paper studies business value indicator as a main criterion of corporation management, reflecting stockholders' interests in their investment profitability increase.

The model of corporation valuation model is represented based on income approach and economic value added (EVA) calculation methods as a sum of predicted values of EVA generated by the corporation discounted to the current period of time. The indicator of economic value added (EVA) was selected as a basic one since it includes factors (NOPAT, WACC, IC) necessary for corporation value management based on process approach. Four levels of variables influencing evaluation outcome are distinguished by means of corporation valuation model factors decomposition.

Economic and mathematical models of individual factors impact assessment on corporation cost value are developed based on the method of model differentiation by distinguished factors, that allows defining degree of impact of each factor on the resulting indicator.

The paper suggests the mechanism of distinguishing key factors of nonpublic corporation value including the algorithm of factors ranging. Such mechanism is of prime importance to corporation management since it allows distinguishing factors having the greater influence on its value, therefore, requiring for more concentrated management activities (planning, control, etc.).
\end{abstract}

Keywords: corporation value, income approach, residual income, Economic Value Added (EVA), evaluation model of degree of corporation value factor impact, value key factors, mechanism of distinguishing value key factors

\section{Introduction}

Corporation value is one of main invested assets efficiency criteria for corporation's shareholders. This indicator forms corporation stock value (equity share), therefore, directly influences shareholders' income. That's why nowadays corporation value-based management is an important task of management that defines relevance of the research.

Value-based management of a nonpublic corporation, i.e. its shares aren't quoted on stock exchange, isn't subject to direct influence of short-term speculative trends of capital market. Management fundamental factors, such as invested capital value, capital sources value, operational profit value, tax take rate on corporate income, etc. have great impact on such corporation value. In such a way, valuation model of nonpublic corporation value should take into account these factors. In their turn, these factors are also management efficiency criteria for corporation's individual processes. In this case the model allows applying process approach to corporation management and defining required measurable values of management efficiency criteria.

Thus, the paper solves the problem of developing evaluation model of nonpublic corporation value for the purpose of applying process approach to value-based management, and also defining quantitative values of criteria of individual processes coordinated management for the purpose of corporation value maximization.

The need in this research, which is of methodological nature, is conditioned by the absence of developments of nonpublic corporation value factors impact estimation. The best part of researches (for example, Grant (2003), Investor Opinion Survey (2012)) concerned with factors influencing business value put an emphasis on statistic 
methods, which imply statistical sampling for detecting factor having greater influence. There are no such data for nonpublic corporations, therefore, this methodology is inapplicable. Moreover, statistical methods allow detecting trends, but since they rely on historical records, they reflect the past, and it's not enough to define the future in corporation development for the purpose of its value maximization.

For the purpose of factors ranging by the degree of their influence on business value the paper presents the author's mechanism of distinguishing key factors of nonpublic corporation value based on the differentiation of relative and absolute factors. Such mechanism is important to distinguish factors of greater influence for the purpose of corporation management actions concentration (planning, monitoring, motivation, etc.).

EVA indicators belonging to the indicator group of residual value (along with ReOI, RE) is selected as a basic one, since it subsequently allows decomposing factors characterizing corporation individual processes.

Thus, the following objective of the research is stated - to decompose corporation cost value on separate factors, to develop evaluation models of each factor influence on final value and mechanisms of distinguishing key factors that will allow providing corporation management with tools to manage value. Since nonpublic corporations have no statistic data on previous value, differentiation methods to evaluate the corporation value sensitivity to factors' change are used in the work.

The issues of business evaluation theory and practice, company strategic management found extensive use in works of Russian and foreign scientists. Approaches and business valuation methods are considered in detail in the works of Brealey and Myers (2010), where the methodology of income approach use in business valuation is represented. Besides the methods of business valuation using income and comparative approaches there are valuation peculiarities of companies from developing countries, startups, financial corporations in Damodaran's monographs (2014).

This research is relied on the results of works concerned with Value Based Management concept of such authors as Copeland (2008), where EVA is used as a basic indicator when valuating and managing corporation value; Edwards E., Bell P., who developed the concept of the model of residual income as a main indicator in business valuation (Edwards \& Bell, 1961). In Fama's and French's work the valuation procedure of corporation required return is described in detail based on three-factor model developing the concept of CAPM (Fama \& French, 2012). In their turn, Barontini's, Caprio's works include the assessment methods of separate factors influence on the result value of corporation cost based on the methods of statistical analysis (Barontini \& Caprio, 2005). Authors' works made an invaluable contribution to development of value theories and defined the role of value approach as a natural factor of the evolutionary processes in economic science. Above-mentioned authors developed new approaches to company evaluation, distinguishing criteria of strategic decisions making, project efficiency estimation, uncertainty analysis and accounting in forecasting.

\section{Methods}

\subsection{Valuation Methodology of Corporation Value in Russian and International Practice of Valuation Activities. Valuation Features of Nonpublic Corporation Value}

In Russian practice of valuation activity for business value calculation in valuation activity regulated by Federal law as of 29.07.1998 N 135-Ф3 (as amended of 12.03.2014) "On valuation activity in the Russian Federation" three main approaches are used: income approach, comparative approach, and cost approach for business value calculation described in FVS No. 2 in accordance with requirements for valuation report. Given this, it is income approach representing "a complex of valuation methods of valuation object, which are based on determining expected incomes from using the valuation object" most accurately reflects business management essence - capability of business future financial results increase.

In international valuation standards income and comparative approaches are main approaches, while cost approach evaluates a corporation as a set of assets that doesn't reflect business capability to generate profits from using this asset complex. For a non-public corporation the use of comparative approach can be considerably impeded by the search for companies-analogues with known market value. That's why income approach is a main approach to nonpublic corporation valuation. It assumes that corporation value is equal to the sum of future incomes, which corporation-invested capital reduced to current time can generate. This approach is also the most important when valuating for the purpose of value-based management since it reflects the ability of management to maximize corporation incomes using the current bundle of assets and taking necessary strategic and tactical management activities.

That's why income approach is a main one in the context of corporation value-based management conception. Many indicators are developed as a basic indicator discounted within the framework of income approach in 
international practice of valuation and value management. Each of them has its advantages.

Specific problem of selection of a basic indicator of company value-based management conception is based on diversity of such indicators.

Situation in this segment of consulting market was accurately defined by the title of a classical article in CFO Magazine (1997) - Measure for measure. It should be noted that over the last years from the date of this paper the situation has become exacerbated.

All the range of indicators is represented in the most systematized way in Volkov's work (2005). The author set indicators in Figure 1 based on selected valuation basis.

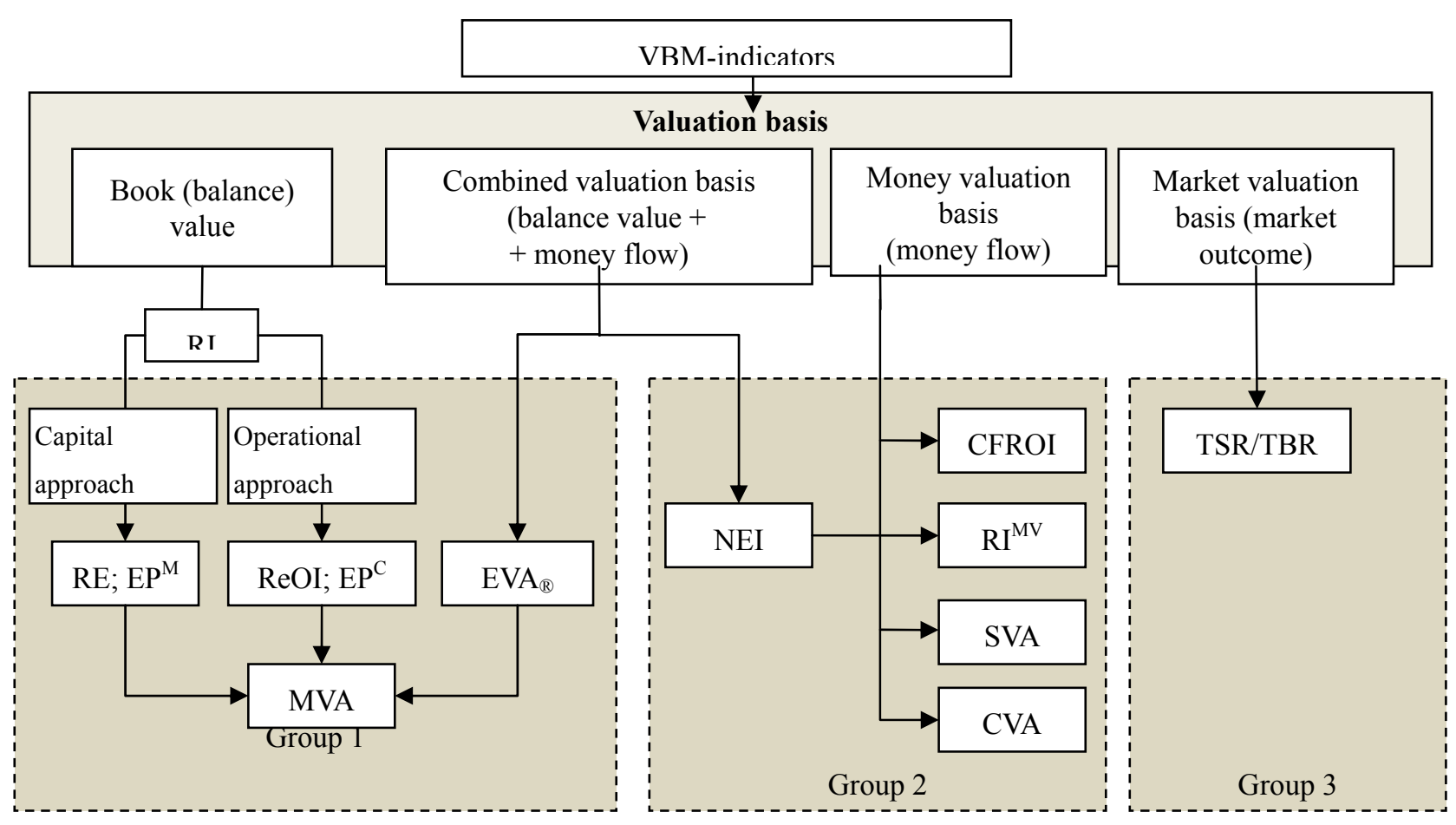

Designations:

RI-residual income;

RE—residual earnings in EBOP (Edwards, Bell, Ohlson \& Penman) model variant;

$\mathrm{EP}^{\mathrm{M}}$ - economic profit in Marakon Associates variant;

ReOI-residual operating income by S. Penman;

$\mathrm{EP}^{\mathrm{C}}$ —economic profit in McKinsey \& Co. variant;

$\mathrm{EVA}_{\mathbb{B}}$ — economic value added in Stern Stewart \& Co. registered variant;

MVA - market value added in various variants;

CFROI - cash flow return on investment in Boston Consulting Group and HOLT Value Associates variant;

$\mathrm{RI}^{\mathrm{MV}}$ —residual income based on market values;

NEI—net economic income;

Figure 1. Set of base indicators of VBM concept

For the purpose of Value Based Management indicators classification, accounting indicators of profit and invested capital, money flows, external indicators are used as a criterion, i.e. directly market, performance 
appraisals, dividing indicators under consideration into three groups

- Group 1-performance indicators based on accounting (balance valuations) and indicators;

- Group 2-performance indicators based on money flows;

- Group 3-performance indicators directly based on market appraisals.

In case of such rough classification criterion intermediate options are possible when in results indicator some combination of monetary and accounting evaluation bases takes place. Economic Value Added (EVA) is one of such indicators.

Economic Value Added (EVA) is a modification of residual operational profit indicator in which both net operational effects and invested capital sum (and expenditures for invested capital, correspondingly) are corrected on so-called capital equivalents. This indicator is developed and promoted by Stern Stewart \& Co. company, primarily, in Stewart's (Stewart, 1999) and Grant's works (Grant, 2003).

The notion of capital equivalents is a key one to understand differences between residual operational profit in the classic and EVA variants. Capital equivalents are addition of balance value of organization's net assets, which are designed to "restore" net assets value to their actual money value determined by monetary payment related to these assets inflow. EVA calculation method allows a researcher to base on process approach concept in corporation management and correspondingly development of the system of management indicators, which forms the model of corporation value as a management efficiency criterion.

Thus, the indicator of economic value added that combines both monetary and accounting assessment bases is selected as a basic one to solve the problems of corporation value-based management factors modeling.

\subsection{Methodology of Nonpublic Corporation Valuation Using Income Approach in the Context of Value Based Management Concept}

In the context of value based management concept stated in the works of Copeland, Koller and Murrin (2008), Kharisova (2011), Economic Value Added (EVA) is a main indicator measuring "employed capital value and absolute monetary increment of shareholders' wealth", i.e. measuring the business value growth.

The model of residual income discounting suggests that "Equity Fundamental Value" (Equity Fundamental Value $-V_{E}$ ) is defined by Book Equity Value at the moment of valuation (Equity Book Value $-E^{B V}$ ) and discounted flow of residual income (RI)" (Volkov, 2005).

Then the basic model of corporation valuation using income approach is the following:

$$
V_{E}=E_{0}^{D V}+\sum_{j=1}^{\infty} \frac{R L_{j}}{(1+k)^{j}},
$$

where $k$-required rate of profitability to capital invested in business;

$j$ - period sequence number.

If economic value added is selected as a residual value indicator, the model of business evaluation based on income approach using EVA is expressed in the following formula:

$$
P_{B}=r C_{0}^{E V}+\sum_{j=1}^{=} \frac{E V A_{j}}{(1+k)^{j}},
$$

where $\mathbf{E V A} A_{/}$-business economic value added value over the $j$-th period;

$I C_{\mathrm{I}}^{B V}$-balance value of capital invested in business over the zero period (i.e. as of valuation date).

The model of business valuation represented by the formula (2) allows calculating business value as a sum of expected future generated residual values aggregated with current balance value of liabilities (invested capital), i.e. reflects current business market value as a complex of enterprise's equity capital and debt capital or assets. It should be noted that in order to valuate business equity capital value it's necessary to deduct invested in enterprise debt capital corrected value from business value computed according to the formula (2).

To valuate business total the entire calculation period designated by an infinity sign in the formula (2) is divided into forecast and post-forecast intervals as it shown in Fig. 2 (Esipov \& Makhovikova, 2012). 


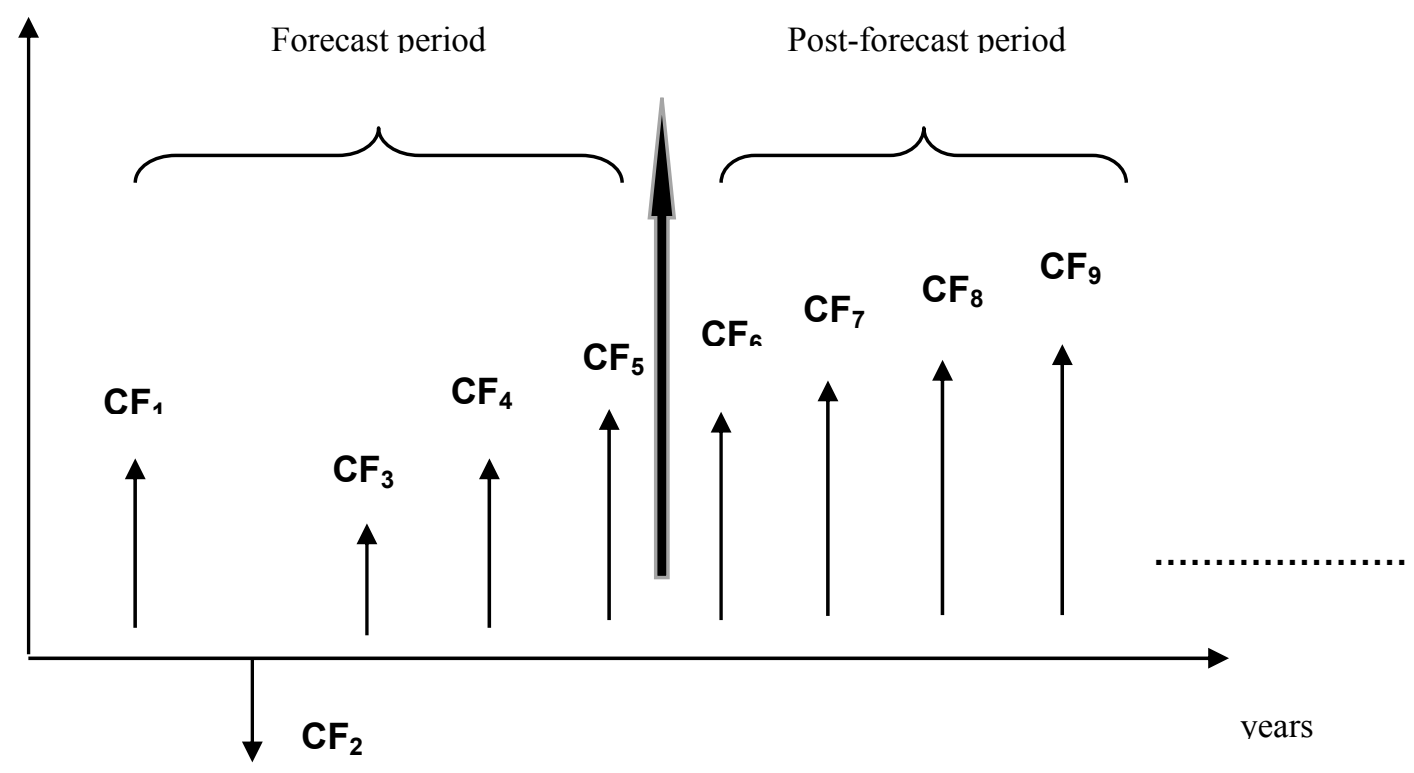

Figure 2. Forecast and post-forecast periods

in corporation valuation

Then business value is calculated in the following way:

$$
F_{E}=I C_{E}^{B V}+V_{E}^{E}+P_{E}^{A E}
$$

Where $V_{E}^{E}$-business value in forecast period;

$$
P_{E}^{A E} \text {-business value in post-forecast period. }
$$

In developing countries, i.a. Russia, forecast period of business development, as a rule, makes up 3-5 years (Gryaznova, 2009). In the framework of this period enterprise activity is forecasted for each separate year, i.e. the model is the following for 3-years forecast period:

$$
P E=\frac{E F A_{L}}{1+k}+\frac{E F A_{2}}{(1+k)^{2}}+\frac{E F A_{\mathrm{g}}}{(1+k)^{3}}
$$

The following methods are used for business valuation in post-forecast period (Gryaznova, 2009).

1) Calculation method by disposal value. It's used in case company's bankruptcy is expected in post-forecast followed by existing assets sale.

2) Calculation method by net asset value (Bukharin \& Ozerov, 2011). This method can be used for stable business, the main feature of which is considerable tangible assets.

3) Method of probable sale involving money flow translation into value indicators by means of special coefficients derived from the analysis of retrospective data on compared companies' sales. Since there is no practice of sales of companies or it's sparse, application of this method for defining final value is quite problematic.

4) According to the Gordon Growth Model, money flow of post-forecast period is capitalized in value indicators by means of capitalization coefficient calculated as a difference between discount rate and long-term rates of growth. In the absence of rates of growth capitalization coefficient will be equal to discount rate. Gordon's rate is based on regular income acquisition forecast in the residual period and assumes that rates of wear and capital investments are the same.

In this paper we use the Gordon Growth Model to valuate business in post-forecast period based on the principle of going concern stated in Stepanov's work (Stepanov, 2008), namely, financial estimates and "financial statements are usually carried out based on the assumption that a company won't dissolve in the foreseeable 
future" (Conceptual framework of financial statements, article 4.1, 2010)

The business value in post-forecast period is calculated according the following formula:

$$
\nabla_{E}{ }^{A}=\frac{E F A_{g}(1+g)}{(r-g)(1+r)^{4}}
$$

where $\mathrm{g}$ - forecasting rate of growth of enterprise's economic value added in post-forecast period.

In general the business valuation model subject to the formulas (3) - (5) is the following:

$$
W_{z}=C C_{6}^{B V}+\frac{E F A_{1}}{1+k}+\frac{B P A_{2}}{(1+k)^{2}}+\frac{E V A_{3}}{(1+k)^{3}}+\frac{E V A_{3}(1+g)}{(r-g)(1+r)^{4}}
$$

Using this model of business valuation we derive business value as a sum of future business economic values added reduced to the current period. In other words, enterprise's future income is a main factor forming value that confirms the objective of any enterprise's operation-generation of incomes for shareholders (owners) (Klimova, 2010).

\subsection{Derivation of Corporation Valuation Model Factors Tree Using Decomposition Method}

Distinguishing value key factors is an especially important stage of business value formation and management.

Derivation of corporation valuation model factors tree is carried out using decomposition method, i.e. based on the model individual indicators calculation methods, distinguishing factors influencing business final value is carried out.

Factors of the $1^{\text {st }}$ order are the model indicators (6), namely: balance value of capital invested in business in the zero period ( $\llbracket C \mathbb{1}_{1} 0^{\top} B V$ ), economic value added $\left(E V A_{l}\right.$ ) in the first, second, third years of forecast period, discount rate (r) and business growth rate in post-forecast period $(\mathrm{g})$.

To distinguish factors of the second order the evaluation model of economic value added indicator:

$$
E P A_{l}-N Q F A T_{j}-I C_{j} * W A C C_{j}
$$

Where $\operatorname{WOPAT}_{\bar{l}}$-net operational income in the $j$-th period;

$J \tilde{C}_{j}$ —value of capital invested in business in the $j$-th period;

WACC $C_{\text {— }}$ weighted average cost of capital in the $j$-th period.

Then factors of the $2^{\text {nd }}$ order influencing business value are factors of the model (7).

To detect factors of the $3^{\text {rd }}$ order let's present the evaluation model of EBIT indicator:

$$
\text { WOPAT }=E B I T_{j} *(1-T)
$$

Where $E B I T_{j}$ _Earnings Before Interest and Tax in the $j$-th period;

$\mathrm{T}$ - profit tax rate.

The following formula is used to compute weighted average cost of capital (WACC):

$$
W A C C=R_{E} \frac{E}{E+D}+R_{D}(1-T) \frac{D}{E+D}
$$

where E-equity capital;

D-debt capital;

$\mathrm{R}_{\mathrm{E}}$-required profitability of equity capital;

$\mathrm{R}_{\mathrm{D}}$-required profitability of debt capital;

$\mathrm{T}$ - profit tax rate.

Thus, factors of the third order $\left(\mathrm{R}_{\mathrm{E}}\right)$ and debt $\left(\mathrm{R}_{\mathrm{D}}\right)$ capitals. 
EBIT is computed according to the following formula:

$$
E B I T_{l}=N_{j}-F C_{l}-F C_{j}
$$

Where $N_{j}$-enterprise's net sales in the $j$-th period;

$F C_{j}$-enterprise's variable charges in the $j$-th period;

$F C_{j}$ _enterprise's fixed expenses in the $j$-th period.

Consequently, factors of the fourth order influencing business value are enterprise's net sales in the $j$-th period

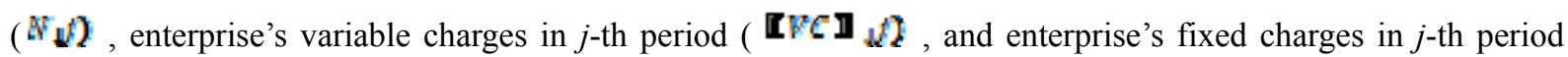
$\left(\llbracket F C \rrbracket_{\Perp}\right)$.

For the valuation model of business value based on income approach with the use of economic value added, reflected in the model (6), hierarchy of business value factors is shown in Fig. 3.

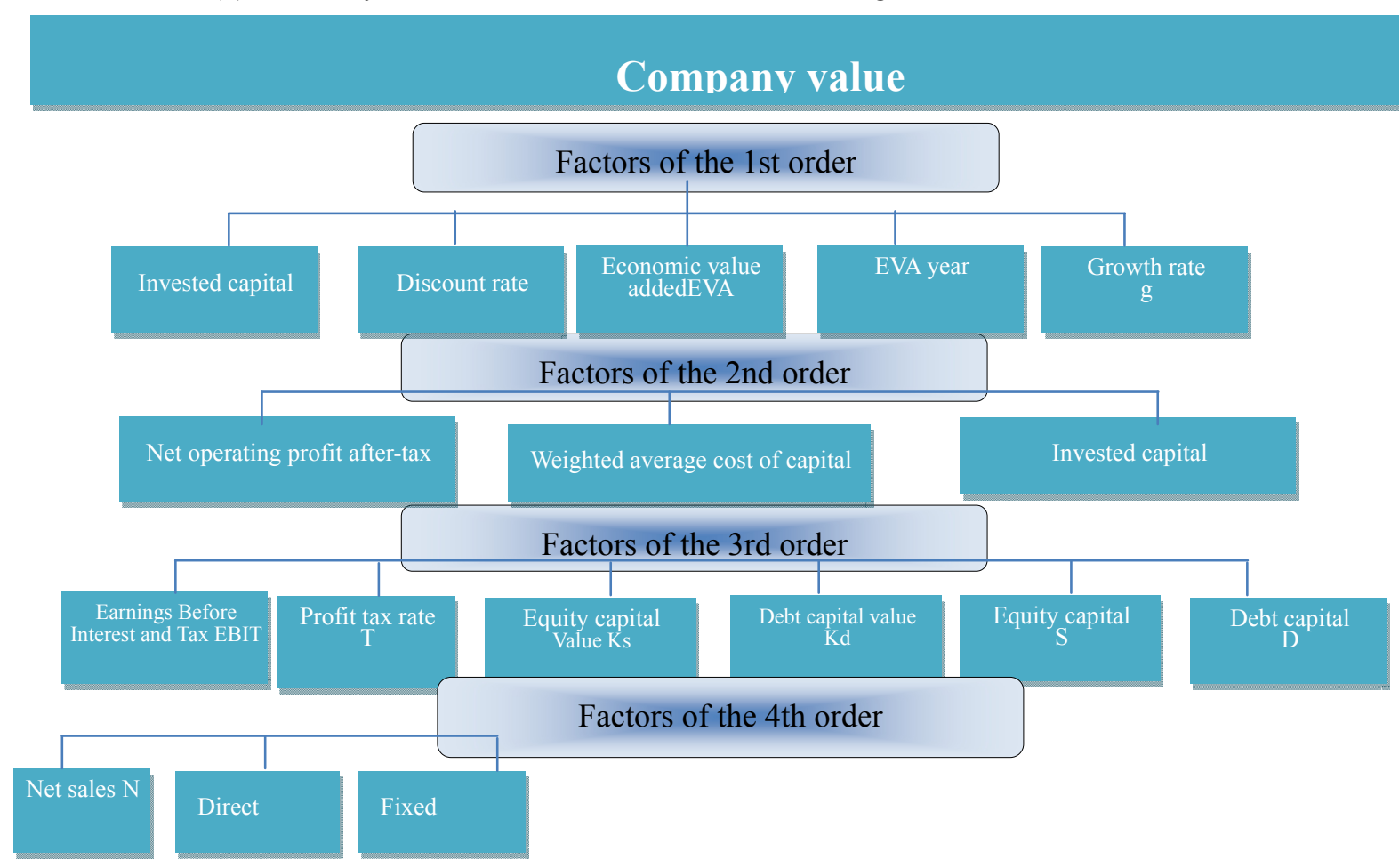

Figure 3. Hierarchy of business value factors

Within the framework of the research the evaluation models of degree of the $1^{\text {st }}$ order factors' influence on business value and mechanism of distinguishing key factors of corporation values are developed.

\section{Results}

\subsection{Development of Economic and Mathematical Models of Evaluation of Degree of Value Factors Impact}

To estimate business value sensitivity to value factors differentiation of the model of evaluation (6) by each of factors was carried out.

3.2 Economic and Mathematical Models of Evaluation of Business Value Sensitivity to the Factors of the $1^{\text {st }}$ Order

Application of model differentiation method by the factors of the $1^{\text {st }}$ order allowed obtaining the following results with their interpretation description.

The evaluation model of the "balance value of capital invested in business in the zero period" value indicator influence degree ( $\square I C \rrbracket_{1} 0^{\top} \bar{D} ?$ ? 


$$
\frac{\partial W_{E}}{\partial I C_{Q}^{B V}}=1
$$

In other words, when increasing (decreasing) the value of capital invested in business in the zero period by a unit, business value also increases (decreases) by a unit. This factor has direct linear influence on business value. I.e. it's necessary and enough to increase invested capital value in order to increase business value. At the same time this factor use for the purpose of value management without corresponding increase in residual income indicators negatively influences business efficiency, since it decreases the indicators values of return on equity (ROE), Return on Total Assets (ROA), Cash Flow Return On Investment (CFROI) and others.

The evaluation model of economic value added factor influence degree during the $1^{\text {st }}$ year $\left(E F A_{1}\right)$ is the following:

$$
\frac{\partial P_{g}}{\partial E V A_{1}}=\frac{1}{1+r}
$$

i.e. when increasing (decreasing) the value of economic value added in the $1^{\text {st }}$ year by a unit, business value increases (decreases) by a unit. Influence of the factor is considered direct, i.e. the growth of economic value added in the $1^{\text {st }}$ year of forecast period leads to business value increase.

The evaluation model of economic value added factor influence degree during the $2^{\text {nd }}$ year $\left(E F A_{\Sigma}\right)$ is the following:

$$
\frac{\partial F_{B}}{S E V A_{2}}=\frac{1}{(1+r)^{2}}
$$

In other words, when increasing (decreasing) the value of economic value added in the $2^{\text {nd }}$ year by a unit, business value increases (decreases) by a unit. Similarly to the previous indicator the model (13) demonstrates direct influence of the factor.

The evaluation model of economic value added factor influence degree during the $3^{\text {rd }}$ year $\left(\mathrm{EVA}_{3}\right)$ is the following:

$$
\frac{O F_{E}}{\partial E F A_{G}}=\frac{1}{(\mathbb{C} 1+r)]^{3}}+\frac{1+g}{(r-g)(\mathbb{1} 1+r)]^{4}} \text {. }
$$

In other words, when increasing (decreasing) the value of economic value added in the $3^{\text {rd }}$ year by a unit, business value increases (decreases) by a unit. This indicator directly influences business value.

Total influence of the factors of economic value added is the following:

$$
\frac{\partial F_{E}}{\partial E V A_{1}}+\frac{\partial F_{E}}{\partial E V A_{2}}+\frac{\partial F_{E}}{\partial E V A_{g}}=\frac{1}{1+r}+\frac{1}{(1+r)^{2}}+\frac{1}{([1+r)]^{3}}+\frac{1+g}{(r-g)([1+r)]^{4}}
$$

The evaluation model of discount rate influence degree $(r)$ is the following:

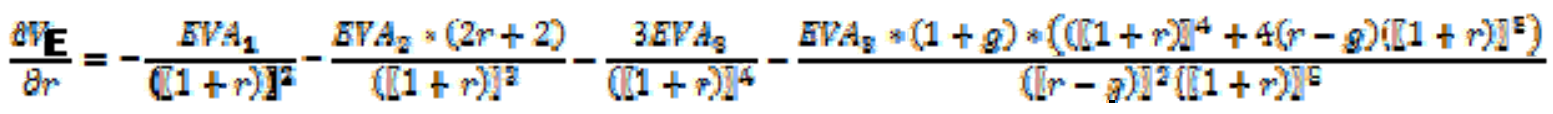

In other words, when increasing (decreasing) the value of discount rate by $1 \%$, business value increases (decreases) by value expressed in the formula (16). It's seen that increase in discount rate that also reflects required profitability of business leads to business value decrease.

The evaluation model of economic value added growth rate influence degree in post-forecast period $(g)$ is the following:

$$
\frac{\partial V_{E}}{\partial g}=\frac{E V A_{3\left((r-g)(1+r)^{4}-4(1+g)(r-g)(1+r)^{3}+(1+g)(1+r)^{4}\right.}}{(r-g)^{2}(1+r)^{8}}
$$

In other words, when increasing (decreasing) rate of growth by $1 \%$, business value increases (decreases) by value expressed in the formula (17). This factor directly influences business value, i.e. increase in rate of growth in post-forecast period leads to business value growth. 
The models represented in the formulas (11) - (17) allow calculating the degree of impact of each factor of business value of the formula (6).

Findings of influence models of absolute factors of the $1^{\text {st }}$ order are shown in Table 1.

Table 1. Evaluation models of degree of absolute factors impact

\begin{tabular}{|c|c|c|c|}
\hline Value factor & Designation & Model of evaluation & \\
\hline $\begin{array}{l}\text { Balance value of invested capital } \\
\text { in the zero (current) period }\end{array}$ & $I C_{0}^{a t}$ & $\frac{\partial \mathrm{F}_{E}}{\partial I C_{\square}^{B V}}=1$ & \\
\hline $\begin{array}{l}\text { Economic value added in the } 1^{\text {st }} \\
\text { year }\end{array}$ & $E / A_{1}$ & $\frac{\varepsilon F_{E}}{\partial E F A_{1}}=\frac{1}{1+r}$ & \\
\hline $\begin{array}{l}\text { Economic value added in the } 2^{\text {nd }} \\
\text { year }\end{array}$ & EVA & $\frac{B P_{Z}}{8 E P A_{2}}=\frac{1}{\left(1+r^{2}\right.}$ & \\
\hline $\begin{array}{l}\text { Economic value added in the } 3^{\text {rd }} \\
\text { year }\end{array}$ & EVA $A_{g}$ & $\frac{\partial V_{g}}{\partial E F A_{g}}=\frac{1}{([1+m)]}$ & $\frac{1+g}{(r-g) \sqrt{1}[1+r)]^{4}}$ \\
\hline
\end{tabular}

Similarly, value factors represented in the form of relative (expressed as a percentage) indicators, are shown in Table 2.

Table 2. Evaluation models of degree of relative factors impact

\begin{tabular}{|c|c|c|}
\hline Value factor & Designation & Model of evaluation \\
\hline Discount rate & $\mathrm{r}$ & 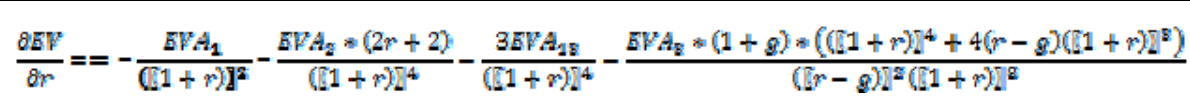 \\
\hline $\begin{array}{l}\text { Rate of economic } \\
\text { value added growth } \\
\text { in post-forecast } \\
\text { period }\end{array}$ & g & 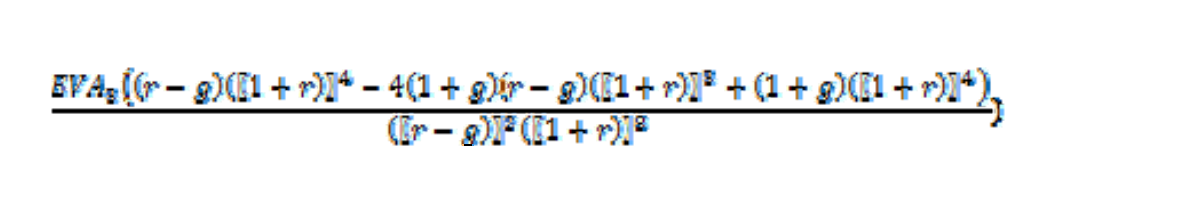 \\
\hline
\end{tabular}

The following model is developed for comparative analysis of the degree of each factor impact:

$$
\theta_{t}=\frac{\left|\sigma_{t}\right|}{\sum_{[-1}^{t} \sigma_{t}},
$$

where $\bar{v}_{i}$-influence value of the $i$-th factor of business value calculated using the models (11) - (17);

$I$ - the number of examined factors;

$\theta_{i}$ - share of influence of the $i$-th factor in the aggregate amount of factors.

Thus, the formula (14) is a model of each factor influence share calculation in the aggregate amount of factors.

\subsection{Mechanism of Distinguishing Key Factors of Corporation Value}

For the purpose of corporation value management the mechanism of distinguishing key factors of corporation value is developed and its implementation mechanism is described. Key factors are factors, the change of which causes most positive or negative influence on corporation final value. Above all things, the mechanism is focused on factors ranging. Corporation management needs it to concentrate management actions (planning, monitoring, motivation, etc.) when manage its value. 
The mechanism of distinguishing value key factors is shown in Figure 4.

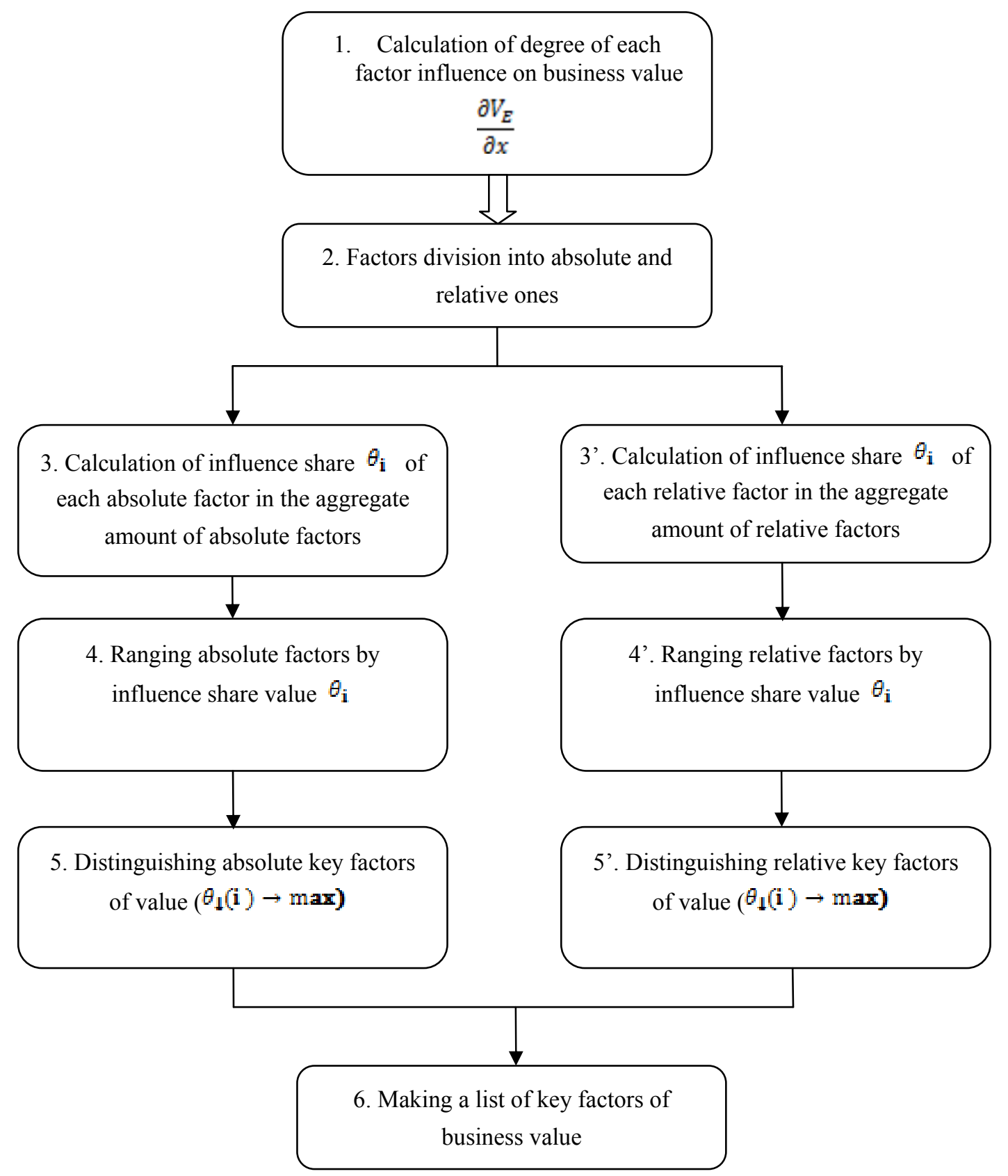

Figure 4. Mechanism of distinguishing key factors of business value

When implementing the mechanism at the first stage it's necessary to conduct computation of influence of each factor influencing business value. Valuation is based on the method of differentiation, i.e. the evaluation model $\frac{\partial V_{E}}{\partial x}$ is examined for each $x$ factor.

The economic and mathematical models given in the formulas (11) - (17) are used to evaluate influence of factors of the $1^{\text {st }}$ order, such as balance value of capital invested in business in the zero (current) period, value of economic value added in forecast period, discount rate, business rate of growth in post-forecast period. 
At the second stage it's necessary to divide factors into absolute ones, i.e. expressed in monetary units, and relative, i.e. expressed as a percentage, shares. When implementing the mechanism it's unacceptable to compare absolute and relative factors since they use different measurement units.

At the third stage the indicator $\theta_{i}$ is calculated for each absolute factor of business valuation model with the use of the algorithm given in the formula (18).

At the fourth stage the factors are ranged by value $\theta_{i}$. A factor that has the highest value of $\theta_{i}$ has the greatest influence since its share in the aggregate amount of absolute factors influence is maximum. When managing business value, enterprise's management should primarily give attention to such factors, since deviation of this factor from planning value leads to business value significant deviation.

Within the $5^{\text {th }}$ stage most significant absolute factors for business value formation are selected. Such factors are called Value Key Factors (VKF). As a rule, in managing such situations the Pareto principle is used, i.e. 20\% of factors that exercise $80 \%$ of influence in the aggregate sum of influence are selected:

$$
\sum_{t=1}^{P} \theta_{t} \approx 0.8
$$

where $P$ - the number of factors having the greatest influence.

The mechanism is implemented at the stages $3^{\prime}-5$ ' in a similar way to the stages 3-5 for relative factors of business value.

At the $6^{\text {th }}$ stage a list of value key factors is made. It's a target list and allows management to concentrate their management actions (planning, monitoring, motivation, etc.) when managing corporation value.

Above all, the mechanism represented allows ranging factors by the degree of corporation value sensitivity to their change. Threshold value for sorting factors into important and not important, subject and not subject to management is determined for each specific corporation individually by its management.

\section{Discussion}

The research results given in the paper are of methodological importance in the field of corporation value management and its formation mechanisms investigation. Findings extend opportunities for valuation, analysis and management of nonpublic corporations' value.

Based on the developed mechanism of distinguishing nonpublic corporation value key factors for Ardatovsky svetotehnichesky zavod JSC (Russia), results are published in Kaluzhskikh's, Spitsyna's work. Table of factors impact degree based on valuation model coefficients as of 01.01.2013 was the following (Tables 3, 4).

Table 3. Analysis of absolute factors impact degree

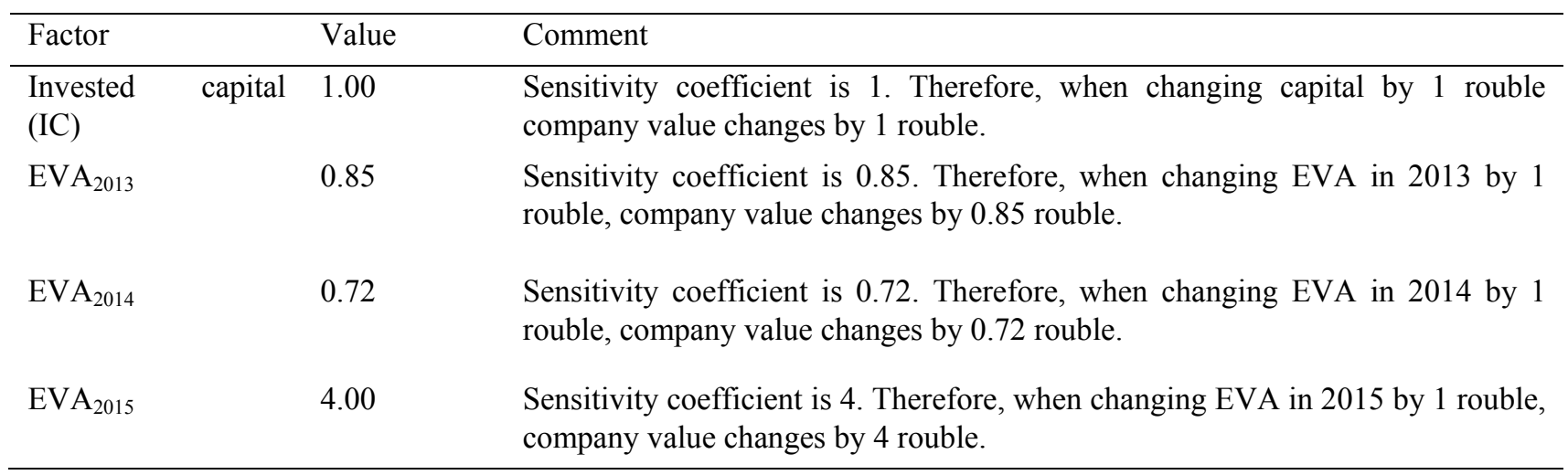


Table 4. Analysis of relative factors impact degree

\begin{tabular}{lll}
\hline Factor & Value & Comment \\
\hline Discount rate (r) & $-0.6 \%$ & $\begin{array}{l}\text { When increasing discount rate by } 1 \% \text { company value decreases } \\
\text { by } 0.6 \%\end{array}$ \\
$\begin{array}{l}\text { Sustainable growth rate } \\
\text { (g) }\end{array}$ & $0.26 \%$ & $\begin{array}{l}\text { When changing rate of growth by } 1 \% \text { company value changes } \\
\text { by } 0.26 \%\end{array}$ \\
\hline
\end{tabular}

According to the mechanism of distinguishing value key factors at the next stage, it's necessary to evaluate factors having the greatest influence on corporation final value (Tables 5-6).

Table 5. Analysis of absolute factors impact degree

\begin{tabular}{llll}
\hline Factor & Value & $\begin{array}{l}\text { Evaluation of influence } \\
\text { degree, } \theta_{i}\end{array}$ & \\
\hline Invested capital (IC) & 1.00 & 0.152 & \\
EVA $_{2013}$ & 0.85 & 0.129 & \\
EVA $_{2014}$ & 0.72 & 0.110 & \\
EVA $_{2015}$ & 4.00 & 0.609 & \\
\hline
\end{tabular}

Table 6. Analysis of relative factors impact degree

\begin{tabular}{llll}
\hline Factor & Value & $\begin{array}{l}\text { Evaluation } \\
\text { degree, } \theta_{i}\end{array}$ & of influence \\
\hline Discount rate $(\mathrm{r})$ & $-0.6 \%$ & 0.698 \\
& & \\
$\begin{array}{l}\text { Sustainable growth } \\
\text { rate }(\mathrm{g})\end{array}$ & $0.26 \%$ & 0.302 & \\
\hline
\end{tabular}

Thus, invested capital $\left(\theta_{1} t=0,152\right)$ and EVA in post-forecast period $\left(\theta_{1} t=0,609\right)$ in the group of absolute indicators and discount rate $\mathrm{r}(\mathrm{l}-\mathbf{0}, \mathbf{6 9 0 6 )}$ in the group of relative indicators are key factors that influence company value most.

When implementing the mechanism represented in the research it is important to take into account short-term nature of results obtained based on differentiation methods application. In other words, when calculating nonpublic corporation value in the next period it's necessary to analyze key factors for newly obtained valuation model and repeat implementing the mechanism. Differentiation methods prevent from obtaining long-term results.

Given this, it should be noted that the set of key indicators for the $1^{\text {st }}$ level factors will be the same, i.e. such factors as invested capital, EVA in post-forecast period, and also discount rate will be always the most influential. Changes will affect only numerical value of impact degree. Given this, for the factors of the $2^{\text {nd }}, 3^{\text {rd }}$, and $4^{\text {th }}$ order the set of value key factors will be fundamentally different depending on model parameters value.

An important task is development of evaluation model of impact degree for key factors of the $2^{\text {nd }}, 3^{\text {rd }}$ orders of business valuation model based on income approach using economic value added indicator. Taking into account existence of low-and middle-level management apart from top management, it's also necessary to attach priorities to them concerning management decision making, namely: to detect what factor of their management activity influences enterprise operation efficiency main criterion — business value - most.

Moreover, it's necessary to study the following interesting problem aspects revealed following the results of carried out work: 
- Development of a mechanism of comparison between significance, relative and absolute factors impact degree of corporation valuation model;

- Development of a mechanism of evaluation of change in factor dynamics, i.e. its change significance to corporation final value;

- If we talk about the factors of the $4^{\text {th }}$ level, in the framework of process approach to corporation management it's necessary to carry out studies with regard to individual business branches operation specific features and corresponding value factors, since their composition will be different for enterprises of different branches of economy;

- It's necessary to range factors of sensitivity for corporations from various branches of economy for the purpose of revealing branch trends, and also evaluation general set of most significant factors for world value system;

- To carry out comparative analysis of data on corporation valuation model sensitivity to its separate factors obtained by the method of differentiation to statistic analysis results.

- To decompose such factors of the $1^{\text {st }}$ order as discount rate and rate of business sustainable growth, which demonstrated specific significance when carrying out quantitative calculations.

\section{Conclusions}

In the context of carried out research the mechanism of distinguishing key factors of nonpublic corporation value based on economical and mathematical modeling of evaluation of each of factors degree of impact on final value, developed by means of differentiating the model by each factor.

Distinguishing business key factors is especially important for enterprise's management since it allows determining operation indicators requiring for special consideration, developed plan of strategic and tactical management actions, activities regarding indicators achievement motivation, means of operational, final monitoring. Making a list of value key factors allows focusing enterprise's heads' efforts on most important indicators.

The research provided us with the following findings:

- Direct comparison of model absolute and relative indicators appeared incorrect when shifting to quantitative calculations. That's why the mechanism of distinguishing value key factors has branching at the $3^{\text {rd }}$ stage;

- Value of economic value added in the last year of forecast period is of critical importance when managing corporation value since it's a basic value for terminal value computation. In other words, importance of corporation ability to generate steady income in the longer term is quantitatively confirmed once again;

- Discount rate is of critical importance when managing corporation value, i.e. corporation risk management system, corporation capital value optimization as factors influencing discount rate are important.

The research results given in the paper are of methodological importance in the field of corporation value management and its formation mechanisms investigation.

\section{Acknowledgments}

This research is a result of work carried out by me and my students at Finance and Credit Department of SSAU under the supervision of Professor, Doctor of Economics Sorokina M. over the last 5 years from the moment of the "Value based management concept" topic development. I'd like to express special gratitude to my students Spitsyna M., Kryukova D., Kitaeva I.; findings of their graduation papers provided the basis for this research; to my graduate students Zavarikhina V., Kisel O., who continue to develop the research topic in their thesis works and in the near future will publish the answers to unresearched issues. I thank Doctor of Economics, Vasilyeva M. $\mathrm{V}$. for consultation in preparation paper manuscript to publishing.

\section{References}

Arnold, G. (2000). Tracing the development of value based management. In G. Arnold, \& M. Davies (Eds.), Value Based Management. Context and Application. NY: John Wiley \& Sons.

Barca, F., \& Becht, M. (2001). The control of corporate Europe. NY: Oxford University Press.

Barontini R., \& Caprio L. (2005). The Effect of Family Control on Firm Value and Performance. Evidence from Continental Europe. Finance Working Paper, 88, 115. Retrieved from http://www.ecgi.org/wp

Berglöf, E., \& Pajuste, A. (2003). Emerging owners, eclipsing markets? Corporate governance in Central and East Europe. In P. Cornelius, \& B. Kogut (Eds.), Corporate Governance and Capital Flows. NY: Oxford University Press. 
Berglöf, E., \& Pajuste, A. (2005). Why do firms disclosure and why? Enforcing corporate governance and transparency in Central and Eastern Europe. Retrieved from http://www.ssrn.com

Brealey, R., \& Myers, S. (2010). Principles of corporate finances (p. 1008). Moscow: Olimp-Business.

Bukharin, N. A., Ozerov, E. S., Pupentsova, S. V., \& Shabrova, O. A. (2011). In E. S. Ozerov (Ed.), Business valuation and management: Textbook (p. 238). St. Petersburg: EM-NiT.

Bukhvalov, A. V., \& Volkov, D. L. (2005). The research of dependence between fundamental value and market capitalization of Russian companies. Series Management, 1, 26-44.

Civil Code of the Russian Federation as of 30.11.1994 N 51-Ф3 (adopted by the State Duma of the Federal Assembly of the Russian Federation 21.10.1994) (as amended of 02.11.2013).

Damodaran, A. (2014). Investment evaluation (p. 1316). Moscow: Alpina Publisher.

Edwards, E. O., \& Bell, P. W. (1961). The theory and measurement of business income. Berkeley and Los Angeles: University of California Press.

Esipov, V. E., \& Makhovikova, G. A. (2012). Business evaluation (p. 141). St. Petersburg: Piter.

Fama, E. F., \& French, K. R. (2012). Size, value, and momentum in international stock returns. Journal of Financial Economics, 105(3), 457. http://dx.doi.org/10.1016/j.jfineco.2012.05.011

Federal law as of 29.07.1998 N 135-Ф3 (as revised of 12.03.2014) "On valuation activity in the Russian Federation".

Grant, J. (2003). Foundation of Economic Value Added (The Frank Fabozzi Series) (2nd ed.). NY: John Wiley \& Son.

Gryaznova, A. G., \& Fedotova, M. A. (2009). Business evaluation (p. 736). Moscow: Finansy i statistika.

Investor Opinion Survey Investor Opinion Survey. (2012). McKinsey, July 2012. Retrieved from http//:www.mckinsey.com/features/investor_opinion/index.html

Kharisova, G. M. (2011). The model of economic value added (EVA) and its application in grounding integrated formations strategy in real economic sector. Upravlenie Ekonomicheskimi Sistemami, 12. Retrieved from http://uecs.ru/uecs-36-122011/item/932-eva-

Klimova, N. V. (2010). Economic analysis (p. 210). St. Petersburg: Piter.

Koller, T., Copeland, T., \& Murrin, G. (2008). Company value: Evaluation and management (p. 576). Moscow: Olimp Business.

Limitovsky, M. A. (2010). Company's sustainable growth and leverage effects. Rossiysky zhurnal menedzhmenta, 2(8), 35-46.

Marathon Rated Best of 20 Oil Firms on Corporate Governance. (2004, January 15). Oil Daily.

Mkhailov, V. (2012). Business value calculation. In iTeam. Retrieved from http://www.iteam.ru/articles.php?tid=2\&pid=1\&sid=20\&id=124

Myers, R. (1997). Measure for measure. CFO Magazine, 13(11), 45-51.

Order of The Ministry of Economic Development and Trade of Russia. (2007). General notions of valuation, approaches to valuation and requirements for valuation (federal valuation standard N 1)" as of July 20, 2007 N256

Order of The Ministry of Economic Development and Trade of Russia. (2007). Valuation goal and kinds of value (federal valuation standard N 2)" as of July 20, 2007 N 255

Order of The Ministry of Economic Development and Trade of Russia on adoption of the federal valuation standard. (2007). Requirements to valuation report (federal valuation standard N 3)" as of July 20, 2007 N 254

Spitsyna, M. (2013). Business valuation (by the example of Ardatovsky svetotehnichesky zavod JSC) (Graduation paper under the supervision of Kaluzhskikh I. A.) (p. 101). SSAU.

Stepanov, K. A. (2008). Going concern in accounting and reporting (p. 128). Kazan Federal University.

Stewart, B. (1999). The quest for value: A guide for senior manager. N. Y.

Volkov, D. L. (2005). Organization of performance indicators in the context of VBM. Rossiysky zhurnal menedzhmenta, 2(3), 198-210. 


\section{Copyrights}

Copyright for this article is retained by the author(s), with first publication rights granted to the journal.

This is an open-access article distributed under the terms and conditions of the Creative Commons Attribution license (http://creativecommons.org/licenses/by/3.0/). 